Article

\title{
Understanding Universality within a Liberal Welfare Regime: The Case of Universal Social Programs in Canada
}

\author{
Daniel Béland ${ }^{1, *}$, Gregory P. Marchildon ${ }^{2,3}$ and Michael J. Prince ${ }^{4}$ \\ ${ }^{1}$ McGill Institute for the Study of Canada, McGill University, Montreal, H3A 0G2, Canada; E-Mail: daniel.beland@mcgill.ca \\ 2 Institute of Health Policy, Management \& Evaluation, University of Toronto, Toronto, M5T 3M6, Canada; \\ E-Mail: greg.marchildon@utoronto.ca \\ ${ }^{3}$ Munk School of Global Affairs and Public Policy, University of Toronto, Toronto, M5S 3K9, Canada \\ ${ }^{4}$ Faculty of Human \& Social Development, University of Victoria, Victoria, V8W 2Y2, Canada; E-Mail: mprince@uvic.ca \\ * Corresponding author
}

Submitted: 5 September 2019 | Accepted: 23 December 2019 | Published: 18 March 2020

\begin{abstract}
Although Canada is known as a liberal welfare regime, universality is a key issue in that country, as several major social programs are universal in both their core principles and coverage rules. The objective of this article is to discuss the meaning of universality and related concepts before exploring the development of individual universal social programs in Canada, with a particular focus on health care and old-age pensions. More generally, the article shows how universality can exist and become resilient within a predominantly liberal welfare regime due to the complex and fragmented nature of modern social policy systems, in which policy types vary from policy area to policy area, and even from program to program within the same policy area. The broader analysis of health care and old-age pensions as policy areas illustrates this general claim. This analysis looks at the historical development and the politics of provincial universal health coverage since the late 1950s and at the evolution of the federal Old Age Security program since its creation in the early 1950s. The main argument of this article is that universality as a set of principles remains stronger in health care than in pensions yet key challenges remain in each of these policy areas. Another contention is that there are multiple and contested universalisms in social policy.
\end{abstract}

\section{Keywords}

Canada; health care; liberal welfare regime; old-age pensions; social policy; universality

\section{Issue}

This article is part of the issue "Universalism' or 'Universalisms' in Social Policies?” edited by Monica Budowski (University of Fribourg, Switzerland) and Daniel Künzler (University of Fribourg, Switzerland).

(C) 2020 by the authors; licensee Cogitatio (Lisbon, Portugal). This article is licensed under a Creative Commons Attribution 4.0 International License (CC BY).

\section{Introduction}

Although universality is typically linked with the social democratic welfare regime associated with Scandinavian countries such as Denmark and Sweden, universal social programs exist in the other welfare regimes, including liberal regimes (Esping-Andersen, 1990). Regardless of the country and welfare regime, however, it is clear that growing demographic, economic, and fiscal pressures have led scholars such as Neil Gilbert (2002) to talk about a rise of social policy targeting and a decline of universality in advanced industrial countries. Other scholars reject this idea of a "universal decline of universality," arguing that universality remains strong in many advanced industrial countries categorized as both social democratic and liberal welfare regimes (Béland, Blomqvist, Goul Andersen, Palme, \& Waddan, 2014). This is in part because the liberal welfare regime, based on the primacy of individual rights rather than on the notion of collective responsibility embedded in the social democratic welfare regime, can still lean towards specific universal policy interventions, if it offers greater equality in 
terms of individual opportunity (Esping-Andersen, 1990; Spicker, 2013)

The objective of this article is to contribute to this ongoing debate about the fate of social policy universality in contemporary advanced industrial societies by examining Canada, a liberal welfare regime in which universal social programs have long played a central role (for an overview see Rice \& Prince, 2013). Our contribution to this debate is both theoretical and empirical. First, we offer a critical discussion of three key concepts that are used in this debate: universalism, universality, and universalization. Second, we discuss the historical and the recent fate of universality in Canada by comparing and contrasting the situation prevailing in the two largest social policy areas in terms of social spending: health care and old-age pensions. This comparative analysis suggests that universality has proved relatively resilient in these two policy areas, in contrast to what has been witnessed in other components of the Canadian welfare regime such as family benefits. The article concludes with a summary of the findings leading to a broader discussion about the history and fate of universality in liberal welfare regimes such as Canada.

\section{Universalism, Universality, and Universalization}

To better analyse universal social policy, we introduce three core concepts-namely, universalism, universality, and universalization. These concepts relate to important political ideas, prominent policy instruments, and social processes of change in program design and service delivery. Associated with each of these concepts are a number of complementary notions as well as counter-ideas that together constitute the normative and ideological context of universal social policy in contemporary welfare states.

In brief, universalism is associated with, among other ideas, the corresponding notions of equality and solidarity alongside the contending ideas of diversity and particularism, universality with the complementary notions of accessibility and social rights (that benefits and services should be available unconditionally as a matter of citizenship or residency) plus the competing ideas of selectivity and deservingness, and universalization with accompanying concepts of belonging and decommodification in opposition to the concepts of separating, categorizing, and privatizing.

Universalism, like other "isms," is a complex, dynamic, and contested discourse of public beliefs. It refers to sets of attitudes, principles, ideas, arguments, normative theories, and frameworks of values expressed by specific individuals, groups, institutions, and social movements. From the academic literature and from public discourse, three dimensions to universalism can be identified. These are universalism as: (1) a vision or visions of preferred relations between citizens, governments, communities, and markets; (2) political claims for and against universal approaches in social policymaking and public services; and (3) a body of academic concepts and theories on social policy and the welfare state.

Universalism articulates explicit conceptions on the state, civil society, families, the market economy, and social policy that can be understood as beliefs regarding a desired mix of responsibilities between and among state and non-state actors in social policy and program provision. Favoured ideas in universalism include communal responsibility, equity, and sharing; equality of opportunity and status for all; and the importance of social inclusion and integration. Other connected "isms" include social democratic versions of collectivism, egalitarianism, and nationalism. In liberal welfare states such as Canada, the United States, and the United Kingdom, strong counter-isms to universalism include economic liberalism, market individualism, traditional familism, and neoconservatism. More specifically in the Canadian context, beliefs about preferred arrangements between state and society link up to ideas of constitutionalism, federalism, and the division of powers, inter-regional redistribution, and the equal treatment of citizens across the country with regard to uniform rules on eligibility, benefit amounts, and benefit duration (Rice \& Prince, 2013).

Academic theories about social policy customarily supportive of universalism include relative conceptions of poverty measures rather than absolute measures; social rights as integral components of modern citizenship regimes; and institutional and redistributive welfare models rather than a residual model for addressing individual and community needs. More recently, from feminist scholars and critical policy analysts, are the concepts of false universalism, differentiated universalism, and interactive universalism (Lister, 2003). These concepts interrogate assumptions about the disembodied and autonomous citizen (and reveal this image to be an artificial universalism), question the supposed impartiality of the universal, with a focus on who is included and who is excluded, and, in our age of identity politics and equality rights in a multinational state, suggest a synthesis between the universal and the plural that seeks to embrace equality and diversity through notions of equity, self-determination, dignity, and inclusion.

Universality is a distinctive governing instrument in social policy which refers to public provisions in the form of benefits, services, or general rules anchored in legislation instead of discretionary public sector programming or provisions in the private sector, the domestic sector, or the voluntary sector, including charitable measures. Accessibility rests on citizenship or residency irrespective of financial need or income, and the benefit or service or rule is applicable to the general population (or a particular age group, such as children or older people) of a political jurisdiction. The operating principle for universal provision is of equal benefits or equal access.

A further expression of this general sense of political community is that financing universal programs is wholly or primarily through general revenue sources. This points to the direct link between general taxation and univer- 
sality because, in contrast to social insurance programs which are typically financed through dedicated payroll contributions paid mostly or wholly by workers and their employers, universal programs depend on the flow of general fiscal revenues associated with income taxes (personal and corporate) and sales taxes. Universal social programs offer social protection independent of one's contributions and labour market status. While social assistance programs, like universal ones, are financed through general revenues, they usually target the poor (either through an income test or a more stringent means test that takes into account both income and personal assets). Universal benefits and services are granted based on citizenship status or residency (sometimes supplemented by age criteria in the case of demogrants like Old Age Security [OAS]), rather than need (social assistance) or past contributions (social insurance).

Universalization refers to social processes of change in program design and service delivery, and, we suggest, comprises two related processes: discursive practices, and sequences of material and institutional processes. The discursive involves such cultural activities as the growing acceptance, circulation, and influence of universal ideas, values, and discourse in public discussions and political debates. The material and institutional dimension of universalization involves concrete activities by governments and other state agencies-for instance, the adoption and extension of universality in design features of income benefits, tax measures, and public goods and services. In this respect, universalization indicates a sustained growth in the number of universal programs or an extension of the scope and adequacy of existing universal social services, cash transfers, and social legislation and human rights. To be sure, universalization has implications for the scope of populations covered and for the patterns of resource allocation and distribution between state and non-state actors.

Both the discursive and material processes contribute to the institutionalization of social rights in a multinational state, constructing distinctive policy architectures of universal values and provisions, in addition to shaping the development of citizenship as a regime of entitlements and obligations. Moreover, this universalization operates at a number of levels of social action, from a single program such as old age pensions and broad policy areas such as universal elementary and secondary education and universal health coverage (UHC) to an overall welfare state (whether federal, provincial, or national) and society in general.

Case studies of social policy areas and groups shed important light on two questions related to universalization: first, on the origins, nature, and extent of universalization; and, second, on processes of de-universalization, which entail the diminishment of universality as a policy instrument and the assertion of ideas of private responsibility, for example, as well as techniques related to selectivity and categorical targeting (Béland, Marchildon, \& Prince, 2019). Social policy studies with historical and comparative perspectives can reveal the rise and fall, and perhaps the rise again, of certain ideas, interests, and instrument choices over an extended period, providing insights into the vulnerability or resiliency of given social programs and policy communities.

Countries with liberal welfare regimes, including Canada, have created universal programs, which exist alongside targeted social assistance and contributory social insurance programs, in large part because of the considerable influence of labour and social democratic parties and/or governments. In Canada, universality is dominant in health care, while it is largely absent from income security policy, a subfield dominated by social insurance (federal employment insurance) and social assistance (provincial welfare). In contrast, the field of old age pensions witnesses a close overlapping of universal programs (OAS), income-tested social assistance (the Guaranteed Income Supplement [GIS]), and social insurance (Canada Pension Plan [CPP]/Quebec Pension Plan [QPP]) benefits. It is to the two policy areas of health care and old-age pensions that we now turn.

\section{Health Care}

UHC-commonly known as Medicare in Canadaemerged in stages in the quarter century immediately following the end of the Second World War. More than any other social policy, Medicare would become the poster child program for universality in Canada. Similar to the National Health Service (NHS) in the United Kingdom, Medicare became the jewel in the crown of the Canadian welfare state due to the average citizen's familiarity with its services and because of the absence of any similar policy in the United States, a country with which Canadians regularly compare themselves. In social democratic welfare regimes, UHC is based on citizenship/residency rather than employment status or social security contributions. Canadian Medicare too is based on citizenship/residency, in this case on the simple fact of residency in any of the 10 provinces and three territories that administer Medicare in this highly decentralized federation. Although actual use of Medicare is triggered by medical need, in fact the right to access is based on the broader principle of citizenship.

Canada is far from unique among high-income countries in having UHC. However, the Canadian approach reflects one of the strongest forms of universality in the world (Marchildon, 2014). The majority of UHC systems in high-income countries permit a separate-albeit highly regulated-private tier of hospital and other medically necessary health services. This is done in various ways including the public subsidization of private health insurance supporting a private delivery system parallel to the public system (e.g., Australia), the non-subsidized purchase of private health services partly through executive benefit packages (e.g., United Kingdom), or the required opting out of UHC by citizens earning above a specified threshold of income (e.g., Germany). In Canada, 
none of these forms are encouraged and some are prohibited. Instead, Medicare is built upon a single-tier of publicly-financed health facilities even if delivery involves a highly mixed and decentralized system of public and private delivery agents (Deber, 2004). Being a decentralized federation, provincial governments rather than the central government are responsible for ensuring coverage as well as financing all Medicare services so that they are free at the point of access. Although there are multiple provincial single-payer UHC systems, they are held together through broad standards set by the federal government that must be met by provincial governments in order to receive their full per capita share of the Canada Health Transfer (Marchildon, 2013; Tuohy, 2009).

This single-tier embodies the right of all citizens to access the same services in the same facilities without a private class or "business-class" tier of higher-quality health services relative to publicly-financed Medicare services. This single-tier aspect was the product of a design successfully implemented in the only Canadian province with an elected social democratic government-the Co-operative Commonwealth Federation (CCF) which would later morph into the New Democratic Party (Dyck \& Marchildon, 2018). These single-payer and single-tier characteristics were essential attributes of the universal hospital coverage program introduced by the CCF government in Saskatchewan in January 1947 (some 18 months before the NHS was implemented) and the universal medical care program implemented by the same administration in July 1962 after a lengthy struggle with organized medicine. These design features were accepted by both Liberal and Progressive Conservative administrations at the federal level and embedded in the conditions and standards set by successive federal administrations, most recently in the Canada Health Act of 1984. Over time, Canadians came to see this strong form of universality as an attribute of citizenship (Cohn, 2005; Romanow, 2002).

Despite the political and popular consensus in favour of Canadian-style Medicare, there has always been a vocal and powerful minority opposed to the strong form of universalism associated with Medicare. Moreover, in recent years, the critiques of Medicare have grown and its basic design principles challenged through the courts. In particular, anti-Medicare forces have advocated for the elimination of uniform coverage to allow for the right to access private insurance and private services along with the introduction of user fees will be necessary to address the perceived shortcomings of Canadian Medicare (Bliss, 2010; Blomqvist \& Busby, 2015; Speer \& Lee, 2016). Increasingly, arguments against single-tier Medicare and the underlying contending values are presented to the courts in cases where plaintiffs argue that the provincial laws and regulations that protect the single-tier aspect of provincial Medicare systems are contrary to individual rights as defined under the Charter of Rights and Freedoms in the Canadian Constitution (Flood \& Thomas, 2018).
While a growing coalition of forces on the political right is attempting to limit Canadian Medicare, the leftwing critique of Canadian Medicare is that the federal government has not been assiduous enough in enforcing national standards against recalcitrant provincial governments and this has led to a steady erosion of the principle of access based on need rather than ability to pay. Indeed, in some of Canada's largest cities, it is possible to avoid wait lists by paying for access to advanced diagnostic tests and some elective but still medically necessary day surgeries. This has created two-tier breaches in what was intended to be a single-tier system.

The left's other major critique of Canadian Medicare is its narrowness. Coverage is limited to hospital, medical care-largely defined as physician services, drugs administered within hospitals, and medically necessary diagnostic services. This means that universal coverage in Canada is narrow compared to other high-income countries with UHC. Although expansion beyond this narrow basket was recommended in the past by two Royal Commissions (Canada, 1964; Romanow, 2002) there has been no significant change to the basic Medicare basket of covered services since the 1960s. At the same time, an increasing proportion of health care service is delivered outside of hospitals by non-physicians and an increasing percentage of prescription drugs are consumed outside of hospitals. Although the Medicare basket included something close to two-thirds of all health care goods and services in Canada in the early 1970s, today Medicare covers something less than one-half of all health care as measured by expenditures-a passive form of privatization or de-universalization.

By the end of the 1970s, provincial governments had begun to fill in some of the gaps created by the narrowness of Medicare through targeted and categorical programs. For example, provincial prescription drug plans were established as safety nets for those without employment-based private health insurance. These plans targeted retired individuals and social assistance recipients. At the same time, provincial governments also subsidized or provided some social care services including home care and long-term facility care, largely selective programmes based on means testing. Operating without national standards, the coverage for such programmes is highly variable across the country. In particular, there is a deep east-west gradient in which public coverage for prescription drugs and public subsidies and services for social care are much thinner in Atlantic Canada than in the rest of the country (Romanow, 2002).

There are also areas of health care that have been almost exempt from public intervention and seem to be subject to the market logic of a liberal state as defined by Esping-Andersen (1990). Dental care is almost exclusively (i.e., $95 \%$ ) financed on a private basis-one of the highest levels of private finance among OECD countries. Vision care is also excluded from Medicare and not part of provincial extended health benefit programmesthough provision is made for both dental and vision care 
in provincial welfare programmes (Marchildon, 2013). These private and targeted public programmes have made the expansion of universal Medicare difficult as the example of pharmaceuticals illustrate.

Canada is the only high-income UHC country in which prescription drugs are not part of the basic UHC coverage. For decades, arguments have been made to add medically necessary prescription drugs to Medicare through a universal Pharmacare programme. However, because only an estimated 7 percent of the population-largely the working poor-are financially prevented from access to necessary medications, the public demand for universal Pharmacare is relatively weak in Canada (Morgan \& Boothe, 2016). Since 2014, there have been increasing calls for universal Pharmacare in Canada from policy experts, organized labour, and some civil society organizations. In 2018, a Parliamentary Committee reported on national Pharmacare with a majority report in favour of adding outpatient drugs to existing provincial and territorial Medicare plans (Parliamentary Standing Committee on Health, 2018).

In response to this recent pressure, the federal government established an Advisory Council on the Implementation of National Pharmacare which delivered its final report and recommendations in June 2019 (Canada, 2019; Grignon, Longo, Marchildon, \& Officer, 2020). The federal government's response to this report will be the most important test of the political viability of the Canadian model of UHC. If the federal government decides that pharmaceuticals should be added to universal coverage on a single-tier and single-payer basis, the recommendation of the Advisory Council, then this will demonstrate that the model can evolve toward greater universalization. If, however, the federal government choses to simply fill some obvious gaps or subsidize premiums for individuals, then this will confirm that the Canadian model of Medicare is in retreat.

\section{Old-Age Pensions}

The modern Canadian pension system gradually took shape during the 1950s and 1960s. As the result of a series of reforms, multilayered arrangements emerged. Three main layers comprise this complex pension system. First, OAS is a universal flat-rate pension supplemented by the GIS, an income-tested program targeted low-income older people. Second, the CPP and the QPP are contributory, earning-related public pension programs. While QPP operates only in the province of Quebec, CPP covers all workers located outside that province. Finally, employer-sponsored Registered Retirement Plans and personal savings accounts known as Registered Retirement Savings Plans constitute the voluntary yet tax-subsidized components of this fragmented pension system (Béland \& Myles, 2005).

Despite this fragmentation, in recent decades, this system has proved quite effective in reducing poverty among older people in Canada. For instance, as Michael
Wiseman and Martynas Yčas suggest (2008), poverty rates among older people are more than three times lower in Canada than in the United States, another liberal country Canada is regularly compared with. As they show, in terms of poverty reduction, Canada also performs much better than the UK and as well as Sweden, a country strongly associated with the universalism and the social-democratic welfare regime. As they argue, this surprising performance is related directly to the relationship between a modest yet universal flat pensionOAS - and a targeted program-GIS-that supplements this flat pension (Wiseman \& Yčas, 2008). The remainder of this section focuses on the history and fate of this flat pension over time.

In 1952, OAS was created as a universal flat pension offering modest cash benefits (originally 40 dollars CDN per month) to people aged 70 and older meeting basic residency criteria. Later on, in 1970, the eligibility age for OAS was lowered to 65. OAS is a purely federal program, a reality that was made possible by a constitutional agreement between the federal government and the 10 provinces. As for the eligibility criteria, they are quite stringent, as one needs to reside in Canada for 40 years in order to receive full OAS benefits (Béland \& Myles, 2005).

In the early-mid 1960s, it became clear that, on its own, OAS could not guarantee the economic security of millions of retirees, a situation that led to the advent of CPP and QPP. The addition of these earnings-related components to Canada's pension system was accompanied by the creation of GIS in 1967. Initially a temporary measure aimed at supporting low-income older people before CPP and QPP could pay full pensions, GIS was later made permanent (Béland \& Myles, 2005). GIS has since remained available to people entitled to OAS benefits who fall under a minimum level of income.

Like GIS, over time OAS became a widely popular program that created large constituencies, a situation that made it more resistant to potential retrenchment, in a policy feedback logic well described by Paul Pierson (1994) in his now classic book Dismantling the Welfare State? This resistance to direct and explicit retrenchment became obvious in the early-mid 1980s, when Canada, like many other advanced industrial countries, faced large public deficits, which led politicians to look for potential fiscal savings through cutbacks in social programs. Because OAS is financed through general revenues, it became an obvious target during that period. Concerns about the long-term consequences of demographic aging also fueled fiscal anxiety about OAS. It is in this context that, in the mid-1980s, newly-elected Progressive Conservative Prime Minister Brian Mulroney attempted to save the federal government money by partially deindexing OAS pensions, which would penalize both current and future retirees while reducing the long-term fiscal liability of the federal government. In part because Mulroney had promised to spare OAS from such cuts during the 1984 federal campaign, the announcement about the deindex- 
ing of OAS pensions less than a year after the election infuriated many older voters, who took the streets to protest against the proposed measure. In the end, facing much criticism, the Mulroney government withdrew from the OAS retrenchment proposal. Yet, four years later, as part of its 1989 budget, the Mulroney government successfully implemented a low-profile fiscal "claw back" of OAS benefits from high income older people. This meant that, currently, 2.2 percent of eligible older people are subject to the full repayment of their OAS pension, while another 4.7 percent are subject to a partial repayment (Office of the Chief Actuary, 2017, p. 89). Better-off older people who receive OAS can minimize the claw back or withholding tax on their benefit through various financial maneuvers: by splitting pension income with their spouse, generating non-taxable investment income, and making use of income tax deductions to lower their net income. Of course, such measures are less likely available to older people with modest income. This example of "social policy by stealth" (Gray, 1990) or, what we would call, partial de-universalization, is consistent with the Pierson's argument that obfuscation is a potentially effective retrenchment strategy (Pierson, 1994).

The 1989 claw back allowed the federal government to save some money on the back of well-off older people, preserving the formal universality of OAS even while undermining it in practice. Less than a decade later, in 1996, the Liberal government of Jean Chrétien announced a pension reform initiative that would formally end universality (that is, total de-universalization) by replacing both OAS and GIS with a new income-tested Seniors' Benefit that would especially benefit low-income older people (Battle, 1997). To reduce potential opposition to a measure that would further penalize high income older people, the change was designed not to affect current retirees. Despite this blame avoidance strategy (Weaver, 1986), the Seniors' Benefit faced much criticism from both the left (because of the way in which benefits for couples would be calculated) and the right (because its income-test was seen as penalizing seemingly responsible workers who save enough for retirement on their own). In the end, as federal budget surpluses started to materialize in the late 1990s, the Seniors' Benefit seemed less and less necessary and, in the face of criticisms, the Liberal government withdrew its proposal in 1998 (Béland \& Myles, 2005).

The Seniors' Benefit was the only major attempt to formally end universality in old-age pensions. After the late 1990s, the only direct effort to retrench OAS occurred in 2012, when a federal Conservative government announced a gradual increase in the eligibility age of OAS and GIS benefits from 65 to 67 between 2023 and 2029 . Immediately decried by the Liberal Party of Canada and the New Democratic Party, this increase was cancelled in 2016 by the newly-elected Liberal government of Justin Trudeau (Harris, 2016).

Overall, it is clear that OAS has been largely spared from extensive, direct retrenchment, which is not the case of other Canadian social programs such as federal Employment Insurance (Campeau, 2005) and provincial social assistance (Béland \& Daigneault, 2015). Yet, this situation should not obscure the long-term impact of low-profile yet consequential provisions like the ongoing claw back which erodes universality over time, and indexation mechanisms which reduces the real value of OAS benefits over time. Although the impact of demographic aging on OAS spending may prove relatively limited, the gradual erosion of the real value of universal benefits means that they will play an increasingly minor role compared to other components of Canada's fragmented pension system, including GIS (Béland \& Marier, 2019). This means that, although universality has been relatively resilient within Canada's pension system, the relative role of OAS as a source of economic security is diminishing within that system, a situation reinforced by the recently announced expansions of CPP and QPP, which will increase the scope of earnings-related pensions. On the whole, we can talk about a formal resilience of universality but a relative weakening of its relative importance within the country's pension system.

\section{Discussion and Conclusion}

Universalism, universality, and universalization-central concepts in our analytical approach-represent salient political ideas, significant policy tools, and societal change processes in contemporary public affairs. While universality based on citizenship or residency undergirds government intervention in health care and old age pensions in Canada (and in elementary and secondary education), other approaches based on social insurance and selective targeting operate simultaneously. The politics of universality are multiple, relating to diverse values and beliefs, several policy instruments and administrative techniques, and demographic and socio-economic trends. Universalism and universality intermingle with other political ideas and policy instruments in both complementary and contentious ways. Debates centre on the quality of public services, the generosity of income benefits, the mode of funding programs, the coverage of the population, and the intended results perceived for families, gender relations, markets, governments, and society overall. In the political life and public discourse of Canada's liberal welfare regime, major ideas include individual and family responsibility, personal achievement, and the work ethic alongside equality of opportunity, equal access to services, and regional equity.

As a public policy technique or instrument, universality gives expression to social citizenship rights and community membership. By comparison, as a policy tool, social insurance relates personal (premium) contributions and workforce attachment to protection against certain shared risks or contingencies of life. Income-tested benefits and fee subsidies acknowledge differential household incomes and the (in)ability to pay, while social assistance and means testing place emphasis on basic liv- 
ing needs, human vulnerability, rationing of public resources, and welfare subsistence.

One of the reasons for the contested nature of universality is that there is no single model of universal policy program design across countries and periods. This was demonstrated by our analysis of the historical development and the politics of provincial UHC since the 1960s and at the evolution of the federal OAS program since its creation in the early 1950s. In Canada, the trajectory of universality has been and remains uneven and varies from one policy area to the next. The example of pensions also illustrates how the interaction among public social programs takes place in a broader institutional and discursive context of liberalism in which private benefits play a major role alongside public policy programs. These private pension and savings schemes remain voluntary in nature, and therefore offer coverage that is far from universal. At the same time, these private programs are publicly supported through tax expenditure subsidies. In pension policy, we see the interplay of different political discourses (universalism and individualism) and program designs (universality and selectivity).

Universalization directs attention to whether a social program or policy field is becoming more universal in terms of its design elements and dominant ideas in the environment. With respect to medicare, we see renewed efforts at upholding the universal features of access and coverage through federal and provincial reinvestments over the past ten to fifteen years, following a period of fiscal restraint. The federal universal elderly benefit, OAS, has also gone through swings in recent times.

More generally, the varieties of policy program design are important when the time comes to analyze the meaning of universality and universalism within a country's welfare regime. For instance, although Canada is widely understood as a liberal welfare regime, its public health care system largely operates according to a universal logic associated with the social democratic regime. As for Canada's pension system, it is liberal in nature in the sense that public benefits are relatively modest and that social assistance, in the form of GIS, plays a key role within that system. Yet, this system, which features a mix of universal, social insurance, and social assistance benefits, offers surprisingly positive outcomes in terms of poverty reductions that are closer to the results of social-democratic welfare states of Denmark and Sweden than the more liberal regimes in the United Kingdom and the United States (Wiseman \& Yčas, 2008). This points, once again, to the need to study the interaction among different types of social programs, which varies over time and across policy areas within the same country. In the end, our analysis points to the need to study the evolution and interaction among concrete policy instruments to grasp the nature and evolution of universality. Universality and its associated concepts of universalism and universalization, along with related ideas of selectivity and social insurance, must be appreciated in the actual institutional and temporal contexts in which they operate and which, in turn, influence their goals, design, and practices. This broad lesson applies to liberal regimes and we believe scholars studying other countries could find this approach useful. Because at least some key universal programs are there to stay even in a liberal country like Canada, more scholarship is needed about the historical development of and the contemporary debates over universalism, universality, and universalization, in advanced industrial nations and elsewhere around the world.

\section{Acknowledgments}

The authors would like to thank Monica Budowski, Daniel Kuenzler, and the three reviewers for their comments and suggestions.

\section{Conflict of Interests}

The authors declare no conflict of interests.

\section{References}

Battle, K. (1997). Pension reform in Canada. Canadian Journal of Aging, 16(3), 519-552.

Béland, D., Blomqvist, P., Goul Andersen, J., Palme, J., \& Waddan, A. (2014). The universal decline of universality? Social policy change in Canada, Denmark, Sweden, and the UK. Social Policy \& Administration, 48(7), 739-756.

Béland, D., \& Daigneault, P.-M. (Eds.). (2015). Welfare reform in Canada: Provincial social assistance in comparative perspective. Toronto: University of Toronto Press.

Béland, D., Marchildon, G. P., \& Prince, M. J. (Eds.). (2019). Universality and social policy in Canada. Toronto: University of Toronto Press.

Béland, D., \& Marier, P. (2019). Universality and the erosion of old age security. In D. Béland, G. P. Marchildon, \& M. J. Prince (Eds.), Universality and social policy in Canada (pp. 103-119). Toronto: University of Toronto Press.

Béland, D., \& Myles, J. (2005). Stasis amidst change: Canadian pension reform in an age of retrenchment. In G. Bonoli \& T. Shinkawa (Eds.), Ageing and pension reform around the world (pp. 252-272). Cheltenham: Edward Elgar.

Bliss, M. (2010). Critical condition: A historian's prognosis on Canada's aging healthcare system. Toronto: C. D. Howe Institute.

Blomqvist, Å., \& Busby, C. (2015). Rethinking Canada's unbalance mix of public and private healthcare: Insights from abroad (Commentary No. 420). Toronto: C. D. Howe Institute.

Campeau, G. (2005). From UI to El: Waging war on the welfare state. Vancouver: UBC Press.

Canada. (1964). Royal commission on health services: Volume 1. Ottawa: Queen's Printer for the Government 
of Canada.

Canada. (2019). A prescription for Canada: Achieving Pharmacare for all-Final report of the Advisory Council on the implementation of national Pharmacare. Ottawa: Government of Canada on behalf of the Advisory Council on the Implementation of $\mathrm{Na}$ tional Pharmacare.

Cohn, D. (2005). Canadian Medicare: Is there a potential for loyalty? Evidence from Alberta. Canadian Journal of Political Science, 38(2), 415-433.

Deber, R. (2004). Delivering health care: Public, not-forprofit, or private? In G. P. Marchildon, T. McIntosh, \& P.-G. Forest (Eds.), The fiscal sustainability of health care in Canada: The Romanow papers, Volume 1 (pp. 233-296). Toronto: University of Toronto Press.

Dyck, E., \& Marchildon, G. P. (2018). Medicare and social democracy in Canada. In R. Lexier, S. Bangarth, \& J. Weier (Eds.), Party of conscience: The CCF, the NDP, and social democracy in Canada (pp. 174-182). Toronto: Between the Lines.

Esping-Andersen, G. (1990). The three worlds of welfare capitalism. Princeton, NJ: Princeton University Press.

Flood, C. M., \& Thomas, B. (2018). A successful charter challenge to Medicare? Policy options for Canadian provincial governments. Health Economics, Policy and Law, 13(3/4), 433-449.

Gilbert, N. (2002). Transformation of the welfare state. New York, NY: Oxford University Press.

Gray, G. (1990). Social policy by stealth. Policy Options, 11(2), 17-29.

Grignon, M., Longo, C. J., Marchildon, G. P., \& Officer, S. (2020). The 2018 decision to establish an Advisory Council on adding pharmaceuticals to universal health coverage in Canada. Health Policy, 124(1), 7-11.

Harris, K. (2016, March 17). Justin Trudeau says OAS eligibility age to return to 65 in 1st Liberal budget. $C B C$. Retrieved from https://www.cbc.ca/news/politics/ trudeau-economy-bloomberg-new-york-1.3495331

Lister, R. (2003). Citizenship: Feminist perspectives (2nd ed.). New York, NY: New York University Press.
Marchildon, G. P. (2013). Health systems in transition: Canada (2nd ed.). Toronto: University of Toronto Press.

Marchildon, G. P. (2014). The three dimensions of universal Medicare in Canada. Canadian Public Administration, 57(3), 362-382.

Morgan, S. G., \& Boothe, K. (2016). Universal prescription drug coverage in Canada: Long-promised yet undelivered. Healthcare Management Forum, 29(6), 247-254.

Office of the Chief Actuary. (2017). Actuarial report on the Old Age Security program as at 31 December 2015. Ottawa: Office of the Chief Actuary.

Parliamentary Standing Committee on Health. (2018). Pharmacare now: Prescription medicine coverage for all Canadians. Ottawa: House of Commons.

Pierson, P. (1994). Dismantling the welfare state? Reagan, Thatcher, and the politics of retrenchment. New York, NY: Cambridge University Press.

Rice, J. J., \& Prince, M. J. (2013). Changing politics of Canadian social policy (2nd ed.). Toronto: University of Toronto Press.

Romanow, R. (2002). Building on values: The future of health care in Canada. Ottawa: Commission on the Future of Health Care in Canada.

Speer, S., \& Lee, I. (2016). Toward a more fair Medicare: Why Canadian health care isn't equitable or sustainable and how it can be. Ottawa: Macdonald-Laurier Institute.

Spicker, P. (2013). Liberal welfare states. In B. Greve (Ed.), The Routledge handbook of the welfare state (pp. 193-201). London: Routledge.

Tuohy, C. H. (2009). Single payers, multiple systems: The scope and limits of subnational variation under a federal health policy framework. Journal of Health Politics, Policy and Law, 34(4), 453-496.

Weaver, R. K. (1986). The politics of blame avoidance. Journal of Public Policy, 6(4), 371-398.

Wiseman, M., \& Yčas, M. (2008). The Canadian safety net for the elderly. Social Security Bulletin, 68(2), 53-67.

\section{About the Authors}

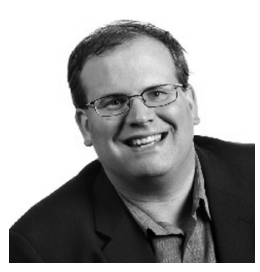

Daniel Béland is Director of the McGill Institute for the Study of Canada and James McGill Professor in the Department of Political Science at McGill University (Canada). A student of social and fiscal policy, he has published more than 140 articles in peer-reviewed journals. He has also published more than 15 books, including An Advanced Introduction to Social Policy (2016; with Rianne Mahon) and Universality and Social Policy in Canada (2019; edited with Gregory P. Marchildon and Michael J. Prince).

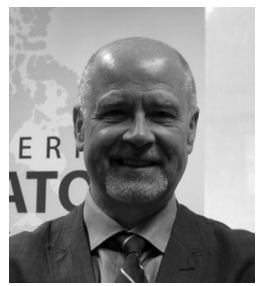

Gregory P. Marchildon holds the Ontario Research Chair in Health Policy and System Design at the University of Toronto (Canada). He has researched and written extensively in the fields of policy history, federalism and comparative health systems and health policy. He has published two editions of Health Systems in Transition: Canada (2018; with Thomas J. Bossert) and is the co-editor of Federalism and Decentralization in Health Care and Bending the Cost Curve in Health: Canada's Provinces in International Perspective (2015; with Livio Di Matteo). 


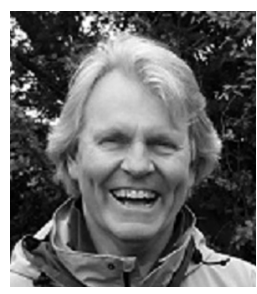

Michael J. Prince holds the Lansdowne Professor Chair of Social Policy at the University of Victoria (Canada). Among his books are Absent Citizens: Disability Politics and Policy in Canada (2009), Changing Politics of Canadian Social Policy (2013; with James Rice), Weary Warriors: Power, Knowledge, and the Invisible Wounds of Soldiers (2014; with Pamela Moss), and Struggling for Social Citizenship: Disabled Canadians, Income Security, and Prime Ministerial Eras (2016). 